\title{
Kinerja DPRD Kota Yogyakarta: Studi Pembentukan Peraturan Daerah Prakarsa DPRD 2019-2020
}

\author{
Muhammad Rizky Saputra ${ }^{*}$, Anom Wahyu Asmorojati \\ ${ }^{1,2}$ Fakultas Hukum, Universitas Ahmad Dahlan, Yogyakarta \\ Jalan Ringroad Selatan, Kragilan, Tamanan, Banguntapan, Bantul, Daerah Istimewa Yogyakarta 55191 \\ *Correspondence email: muhammad1700024050@webmail.uad.ac.id, anom.asmorojati@law.uad.ac.id
}

\begin{abstract}
Abstrak. Pelaksanaan pembentukan Peraturan Daerah yang berasal dari DPRD Kota Yogyakarta pada tahun 2019-2020 dinilai belum optimal dalam kinerjanya mengusulkan Raperda, hal tersebut dibuktikan dengan jumlah Raperda pada tahun 2019-2020 atas prakarsa DPRD Kota Yogyakarta dinilai masih relatif rendah atau sedikit yang hanya mengusulkan 4 Raperda dibandingkan dengan prakarsa eksekutif yang mengusulkan 15 Raperda. Selanjutnya, faktor-faktor yang mempengaruhi kinerja Anggota DPRD Kota Yogyakarta dalam melaksanakan fungsi pembentukan Peraturan Daerah yaitu kurangnya pengalaman berorganisasi anggota DPRD Kota Yogyakarta, latar belakang pendidikan yang berbeda, dan masyarakat kurang antusias berpartisipasi dalam pembentukan Peraturan Daerah. Penelitian ini bertujuan untuk menganalisis fungsi legislasi dan kinerja DPRD Kota Yogyakarta dalam prakarsa pembentukan Peraturan Daerah berdasarkan Peraturan Dewan Perwakilan Rakyat Daerah Kota Yogyakarta Nomor 1 Tahun 2018 tentang Tata Tertib dan bertujuan mengetahui faktor-faktor yang mempengaruhi kinerja Anggota DPRD Kota Yogyakarta dalam melaksanakan Fungsi pembentukan Peraturan Daerah. Penelitian ini menggunakan metode yuridis normatif dan yuridis empiris.
\end{abstract}

Kata Kunci: Fungsi Legislasi; Prakarsa DPRD Kota Yogyakarta; Rancangan Peraturan Daerah.

\begin{abstract}
Implementation the formulation of Regional Regulation by the Yogyakarta Legislative Council was not optimum, especially regarding the performance in proposing the draft bylaws. It was evidenced by the number of drafts from 2019-2020 from the Initiatives of Yogyakarta Legislative Council, which were only 4 draft bylaws, a quite low number compared to the executive which proposed 15 draft bylaws. Furthermore, the factors affecting the performances of the members of the Yogyakarta Legislative council in carrying out its function to formulate the regional regulations were the lack of experiment in organizations, different and limited backgrounds of education, and the lack of people's enthusiasm to participate in the formulation of Regional Regulations. This study aims to analyze the implementation of the legislative functions of The Yogyakarta Legislative Council in the formulation of Regional Regulation Initiatives based on the Regulation of the Yogyakarta Legislative Council Number 1 Year 2018 on Code of Conduct and to find out the factors affecting the performance of the members of the Yogyakarta Legislative Council in implementing their functions in the formulations of regional regulations. This study employed an the normative legal and empirical legal method.
\end{abstract}

Keywords: Legislative functions; The Yogyakarta Legislative Council Initiatives; Draft by laws.

\section{PENDAHULUAN}

Negara Indonesia adalah Negara Kesatuan yang berbentuk Republik sebagaimana yang dimaksud dalam Pasal 1 ayat (1) Undang-Undang Dasar Negara Republik Indonesia Tahun 1945 (UUD 1945) yang wilayahnya terdiri atas beberapa daerah provinsi dan dibagi lagi menjadi daerah kabupaten atau daerah kota sehingga masing-masing daerah tersebut memiliki pemerintahan daerah.

Pemerintahan daerah memiliki kewenangan untuk mengatur maupun mengurus sendiri urusan pemerintahan dengan dasar asas otonomi dan pembantuan yang tertuang dalam Pasal 18 ayat (2) UUD 1945 yang tujuannya berimplementasi pada kesejahteraan umum dengan berdasarkan pembukaan UUD 1945. Hakekat yang dimiliki otonomi daerah yaitu untuk mampu mengembangkan masyarakat Indonesia yang otonom, dengan memberikan kebebasan untuk terbukanya potensi-potensi terbaik yang dimiliki pada setiap individu secara baik. Dalam melaksanakan otonomi daerah, Peraturan Daerah hanya mengatur kepentingan dari masyarakat dan urusan pemerintahan yang tidak diatur oleh pusat, ${ }^{1}$ sehingga penyusunan Peraturan Daerah perlu direncanankan secara optimal, agar seluruh perangkat hukum yang berkaitan dalam rangka penyelenggaraan otonomi daerah dapat dibentuk secara sistematis, terarah, dan terencana berdasarkan dengan skala prioritas yang jelas. ${ }^{22}$ Adanya partisipasi dan peran serta dari pihak masyarakat dapat membantu untuk tercapainya otonomi daerah, dalam hal mewujudkan otonomi daerah maka Dewan Perwakilan Rakyat Daerah (DPRD) yang merupakan unsur pemerintah daerah yang dipilih

\footnotetext{
${ }^{1}$ Huda, Ni'Matul, Otonomi Daerah, Filosofi, Sejarah Perkembangan dan Problematika, (Yogyakarta: Pustaka Belajar, 2013.), hlm.234.

2 Fioren Maria Lasut. "Analisis Fungsi Legislasi Dewan Perwakilan Rakyat Daerah (DPRD) Kota Manado Dalam Pembentukan Peraturan Daerah", Jurnal Lex Administratum, Vol. 6 No. 4, (September 2018): 124.
} 
langsung melalui pemilu oleh masyarakat sebagai lembaga legislatif daerah harus mengedepankan kepentingan rakyat. ${ }^{3}$ Peraturan Daerah menjadi instrumen yang penting untuk membantu meningkatkan perekonomian dan kesejahteraan daerah. ${ }^{4}$ Kata kunci dari otonomi daerah adalah kewenangan, yaitu sebagai pendelegasian kewenangan dari pemerintah pusat kepada pemerintah daerah. ${ }^{5}$ Sehingga semakin besar kewenangan yang digunakan untuk kepentingan dalam mensejahterakan masyarakat, maka semakin bermanfaat implementasi otonomi daerah tersebut. Otonomi bertitik pangkal dari adanya wewenang dan hak untuk melakukan prakarsa maupun dapat memutuskan untuk mengurus dan mengatur daerahnya sendiri dengan kepentingan untuk kesejahteraan masyarakat dengan membentuk Peraturan Daerah yang tidak bertentangan dengan konstitusi negara. ${ }^{6}$ Dalam pelaksanaan otonomi daerah berdasarkan Undang-Undang Nomor 23 Tahun 2014 tentang Pemerintah Daerah, terdapat tiga macam asas-asas otonomi daerah, yaitu desentralisasi, dekonsentrasi, dan tugas pembantuan. Bedasarkan konseptual teoritis dikenal adanya bentukbentuk desentralisasi yaitu: Desentralisasi Teritorial, Desentralisasi Fungsional, Desentralisasi Politik, Desentralisasi Kebudayaan, Desentralisasi Administratif. ${ }^{7}$

Dalam hal pembentukkan Peraturan Daerah untuk menghasilkan Peraturan Daerah maka sebelum disahkan dan diundangkan di Lembaran Daerah perlu dirancang dalam bentuk Rancangan Peraturan Daerah. Anggota DPRD sesuai Pasal 26 ayat (1) huruf a Peraturan DPRD Kota Yogyakarta Nomor 1 Tahun 2018 tentang Tata Tertib mempunyai hak dalam mengajukan Rancangan Peraturan Daerah sehingga pengajuan bukan hanya bersumber dari pihak eksekutif atau disebut Walikota akan tetapi Anggota DPRD juga mempunyai prakarsa untuk menjalankan fungsi inisiatifnya untuk melaksanakan pembentukan Peraturan Daerah. Dalam Pasal 365 ayat (1) UU Nomor 17 Tahun 2014 tentang MPR, DPR, DPD, dan DPRD memiliki tiga fungsi yang salah satu fungsinya yaitu legislasi, fungsi legislasi memiliki tujuan yang berkaitan dengan pembentukan Peraturan Daerah sebagai produk hukum yang memiliki kekuatan mengatur dan mengikat dengan melihat keadaan hukum masyarakat di daerah tersebut. Dalam fungsi legislasi maka Anggota DPRD harus mempunyai pemahaman dan kemampuan dalam membuat produk hukum sehingga hasil dari produk hukum yang dibuat berdampak baik pada kepentingan masyarakat. Dalam hal pembuatan produk hukum kurang baik dapat disebabkan oleh dua faktor yang mempengaruhi kinerja dari legislasi DPRD sehingga fungsi dewan belum berjalan secara optimal disebabkan faktor internal atau faktor eksternal. Faktor internal yang berasal dari DPRD yaitu meliputi kualitas anggota DPRD, Peraturan Tata Tertib DPRD, fasilitas, tenaga ahli, data, dan informasi. Untuk faktor eksternal bukan berasal dari anggota DPRD meliputi budaya politik, sistem politik, dan media. ${ }^{8}$

Anggota DPRD Kota Yogyakarta dalam segi kuantitas sampai sekarang masih kurang dalam pembentukan Peraturan Daerah baru yang menitik beratkan pada kesejahteraan masyarakat yang dihasilkan oleh DPRD Kota Yogyakarta. Pada Pembentukan Peraturan Daerah prakarsa DPRD Kota Yogyakarta selama tahun 2019 sampai dengan 2020 hanya mampu mengusulkan sebanyak 4 Rancangan Peraturan Daerah jumlah tersebut dinilai masih rendah atau sedikit dibandingkan dengan jumlah Peraturan Daerah prakarsa dari pihak eksekutif yang berjumlah 15 Rancangan Peraturan Daerah pada tahun yang sama sehingga hal tersebut dapat dikatakan bertolak belakang dengan penguatan fungsi legislasi yang ada dalam Peraturan DPRD Kota Yogyakarta Nomor 1 Tahun 2018 tentang Tata Tertib yang mengamanatkan wewenang dan tugas dari DPRD salah satunya adalah membentuk Peraturan Daerah sebagai fungsi legislasi, dengan demikian dalam penelitian ini berusaha memberikan evaluasi dalam bentuk hasil penelitian sehingga bisa menjadi sumber data atau referensi kepada Anggota DPRD Kota Yogyakarta Periode 20192024 dalam kinerjanya yang sudah dilaksanakan pada tahun 2019 sampai 2020 yang dapatkan dalam observasi awal menyebutkan DPRD Kota Yogyakarta dalam melaksanakan prakarsa Pembentukan Peraturan Daerah masih relatif rendah atau sedikit dibandingkan dari prakarsa eksekutif sehingga dalam penelitian ini memiliki hasil yang diharapkan dapat membantu dalam memaksimalkan 3 tahun sisa kinerja DPRD Kota Yogyakarta di tahun 2021 sampai dengan 2024 dalam pelaksanaan untuk meningkatkan kuantitas dan kualitas Pembentukan Peraturan Daerah prakarsa DPRD menjadi lebih baik.

Sampai saat ini DPRD Kota Yogyakarta masih menggunakan Peraturan Daerah lama yang seharusnya perlu untuk diperbaharui dengan melaksanakan prakarsa Pembentukan Peraturan Daerah yang berorientasi pada kondisi masyarakat saat ini. Seperti salah satu Peraturan Daerah Kota Yogyakarta Nomor 23 Tahun 2009 tentang

${ }^{3}$ Gaffar, Janedjri M, Demokrasi dan pemilu di Indonesia, (Jakarta: Konstitusi Press, 2013), hlm.37.

${ }^{4}$ Sirajuddin, Hukum Administrasi Pemerintah Daerah, (Malang: Setara Press, 2016), hlm.185.

${ }^{5}$ Dayanto. "Pendayagunaan Hak Inisiatif Anggota DPRD Dalam Pembentukan Peraturan Daerah (Studi Yuridis Sosiologis Di DPRD Sulawesi Selatan)", Jurnal Hukum dan Syariah: Tahkim, Vol. 10 No. 2, (Desember 2014): 147.

6 Moh Rusli Syuaib. "Fungsi Dewan Perwakilan Rakyat Daerah (DPRD) Dalam Pelaksanaan Otonomi Daerah di Kabupaten Poso". Jurnal Ilmiah Administratie, Vol. 2 No. 2, (2014) : 30.

7 Asmorojati, Anom Wahyu, Hukum Pemerintahan Daerah \& Daerah Istimewa Yogyakarta Dalam Bingkai NKRI, (Yogyakarta: UAD Press, 2020), hlm.22.

${ }^{8}$ Rosiani Pratiwi. "Pelaksanaan Fungsi Legislasi Dewan Perwakilan Rakyat Daerah Kabupaten Sanggau Dalam Pembuatan Peraturan Daerah Tahun 2017", Jurnal fisipuntan, Vol. 7 No. 2, (Juni 2019) : 7. 
Penanggulangan Kemiskinan di Kota Yogyakarta dalam implementasi kebijakan secara keseluruhan masih belum memberikan dampak yang maksimal terhadap masalah kemiskinan di Kota Yogyakarta, pada tahun 2016 angka kemiskinan di Daerah Istimewa Yogyakarta mencapai 13,1\% atau dapat dikatakan tertinggi se-Pulau Jawa dan ini berdampak juga pada kabupaten-kabupaten di Yogyakarta seperti di Kota Yogyakarta. Selanjutnya, kendala pada pelaksanaan prakarsa DPRD Kota Yogyakarta dalam pembentukkan Rancangan Peraturan Daerah salah satunya dapat dilihat dari faktor eksternal maupun internal, seperti Rancangan Peraturan Daerah Disabilitas Kota Yogyakarta yang diusulkan pada tahun 2015 dan diakhir tahun 2017 Rancangan Peraturan Daerah Disabilitas Kota Yogyakarta ditolak oleh Biro Hukum Pemerintah Daerah DIY, setelah dicermati ternyata draf yang diajukan terdapat 90 persen dibuat dari hasil mengcopy paste Undang-Undang Nomor 8 Tahun 2006 tentang Penyandang Disabilitas. Karena Peraturan Daerah harus bersifat teknis dan Undang-Undang masih bersifat umum (makro) atau bersifat nasional sudah pasti hal plagiarisme tersebut tidak bisa diterapkan di Kota Yogyakarta.

Disamping prosedur yang kurang efektif dari Raperda sampai pengesahan Perda, seperti salah satu Raperda yang pengesahannya cukup lama dan membutuhkan waktu beberapa tahun yaitu Raperda Pemberdayaan dan Perlindungan Disabilitas yang diusulkan oleh Komisi D DPRD Kota Yogyakarta pada tahun 2013 yang pembahasannya terhambat dan akhirnya pengesahannya dapat dilaksanakan pada tanggal 1 Maret 2019 yang melahirkan Peraturan Daerah No. 4 Tahun 2019 tentang Pemajuan, Perlindungan, dan Pemenuhan Hak-hak Disabilitas. Dari segi efektivitas, Rancangan Peraturan Daerah tersebut sangat memakan waktu yang lama untuk sampai pada pelaksanaan pengesahan menjadi Peraturan Daerah sehingga mengakibatkan jumlah Peraturan Daerah yang dihasilkan saat ini masih sedikit. Tujuan penelitian ini adalah menganalisis kinerja dan fungsi legislasi DPRD Kota Yogyakarta dalam prakarsa Pembentukan Peraturan Daerah berdasarkan Peraturan Dewan Perwakilan Rakyat Daerah Kota Yogyakarta Nomor 1 Tahun 2018 tentang Tata Tertib dan untuk mengetahui faktor-faktor yang mempengaruhi kinerja Anggota DPRD Kota Yogyakarta dalam melaksanakan Fungsi Pembentukan Peraturan Daerah.

\section{METODE}

Jenis penelitian ini adalah penelitian yuridis normatif dan yuridis empiris atau dikenal dengan penelitian normatif-empiris. Penelitian yuridis normatif merupakan penelitian hukum yang dilakukan dengan meneliti serta menelaah peraturan perundang-undangan atau literatur-literatur yang berhubungan dengan permasalahan yang diteliti, pendekatan ini berfokus untuk meneliti bahan pustaka atau disebut penelitian kepustakaan, yaitu dengan mempelajari buku-buku, peraturan perundang-undangan, definisi-definisi, pendapat dari para ahli, dan dokumen yang memiliki keterikatan dengan penelitian, sehingga bahan utama yang ditelaah yaitu bahan hukum sekunder, bahan hukum primer, dan bahan hukum tersier. ${ }^{9}$ Penelitian yuridis empiris merupakan pendekatan yang dilakukan dengan cara penelitian lapangan yang bertempat di kantor DPRD Kota Yogyakarta sehingga diperoleh data dalam penelitian ini yaitu melaksanakan penelitian terkait dengan fungsi legislasi pembentukan Peraturan Daerah prakarsa DPRD Kota Yogyakarta Periode 2019-2020.

Dalam penelitian ini bahan hukum yang digunakan adalah:

1. Bahan Hukum Primer

Bahan hukum primer adalah bahan hukum dari peraturan perundang-undangan yang berkaitan sesuai masalah yang akan diteliti, yaitu:

a. Undang-Undang Dasar 1945;

b. Undang-Undang Nomor 15 Tahun 2019 tentang Perubahan Atas UU Nomor 12 Tahun 2011, tentang Pembentukan Peraturan Perundang-Undangan;

c. Undang-Undang Nomor 42 Tahun 2014, tentang Perubahan Atas UU Nomor 17 Tahun 2014, tentang MPR, DPR, DPD, dan DPRD;

d. Undang-Undang Nomor 9 Tahun 2015, tentang Perubahan Kedua Atas UU Nomor 23 Tahun 2014, tentang Pemerintahan Daerah;

e. Peraturan Dewan Perwakilan Rakyat Daerah Kota Yogyakarta Nomor 1 Tahun 2018 tentang Tata Tertib.

2. Bahan Hukum Sekunder

Bahan hukum sekunder dapat dikaitkan dengan bahan hukum primer karena literatur berupa buku-buku hukum, dokumen, dan lain-lain yang masih berkaitan dalam penelitian.

3. Bahan Hukum Tersier

Bahan hukum tersier berhubungan erat dengan bahan hukum primer dan bahan hukum sekunder dalam memberikan penjelasan yang dapat membantu data penelitian seperti Kamus Besar Bahasa Indonesia dan Inggris, Ensiklopedia, dan Kamus Hukum.

\footnotetext{
${ }^{9}$ Ngani, Nico, Metodologi Penelitian dan Penulisan Hukum, (Yogyakarta: Pustaka Yustisia, 2012), hlm.179.
} 
Teknik pengumpulan data menyesuaikan terhadap permasalahan yang terdapat pada penelitian ini sehingga dilakukan dengan cara:

1. Studi Pustaka

Studi Pustaka adalah pengumpulan data dengan cara menganalisa, membaca, maupun memahami isi pustaka dan menelaah lebih dalam terkait peraturan perundang-undangan tentang fungsi legislasi yang merupakan hak dari Anggota DPRD sehingga dapat mengumpulkan data-data yang sesuai dengan penelitian. Studi pustaka sebagai sarana dalam mendapatkan data sekunder yang meliputi bahan hukum, sekunder, primer, dan tersier dapat dilaksanakan dengan inventarisasi dari bahan-bahan hukum yang sesuai dalam pokok permasalah penelitian.

2. Dokumen-Dokumen

Penelitian ini dilakukan dengan mengumpulkan data berupa dokumen yang berhubungan dengan masalah penelitian, yaitu:

a. Jumlah Rancangan Peraturan Daerah yang diinisiasi oleh DPRD Kota Yogyakarta pada periode 2019-2020;

b. Jumlah Peraturan Daerah yang disahkan pada periode 2019-2020.

3. Wawancara

Wawancara adalah percakapan yang dilakukan dua arah untuk mengumpulkan data penelitian, yaitu dilakukan dengan mengajukan pertanyaan oleh pewawancara kepada responden atau narasumber yang akan menjawab pertanyaan sesuai dengan penelitian atau pokok permasalahan. Narasumber dalam penelitian ini berjumlah 2 orang, yaitu:

a. Bapak OY selaku Wakil Ketua Komisi B DPRD Kota Yogyakarta merangkap Anggota Bapemperda;

b. Bapak PA, S.H. selaku Kepala Bagian Perundang-Undangan dan Humas Sekretariat DPRD Kota Yogyakarta.

Metode analisis data dalam penelitian ini menggunakan metode deskriptif kualitatif, yaitu analisis data diperoleh dari studi Pustaka dan juga diperoleh dari studi lapangan yang dilakukan secara sistematis dan logis, sehingga data yang diperoleh baik secara lisan atau tertulis dapat menjawab permasalahan penelitian dan kemudian hasilnya dapat disimpulkan dan pada penelitian deskriptif kualitatif yang menjawab pertanaan tidak dinamakan responden akan tetapi dinamakan narasumber, informan, dan partisipan. ${ }^{10}$ Teknik analisis data ini digunakan untuk mendeskripsikan penelitian tentang Pelaksanaan Fungsi Legislasi Berdasarkan Peraturan Dewan Perwakilan Rakyat Daerah Kota Yogyakarta Nomor 1 Tahun 2018 tentang Tata Tertib (Studi Terhadap Pembentukan Peraturan Daeran Prakarsa DPRD Kota Yogyakarta Tahun 2019-2020).

\section{HASIL DAN PEMBAHASAN}

Pelaksanaan Fungsi Legislasi DPRD Kota Yogyakarta dalam Prakarsa Pembentukan Peraturan Daerah berdasarkan Peraturan Dewan Perwakilan Rakyat Daerah Kota Yogyakarta Nomor 1 Tahun 2018 tentang Tata Tertib

Pelaksanaan Fungsi Legislasi DPRD Kota Yogyakarta dapat dilihat dari hak anggotanya. Hak Anggota DPRD Kota Yogyakarta yang berhubungan langsung dengan Fungsi Legislasi yaitu mengajukan prakarsa Rancangan Peraturan Daerah dengan berdasarkan Pasal 52 huruf a Peraturan Dewan Perwakilan Rakyat Daerah Kota Yogyakarta Nomor 1 Tahun 2018 tentang Tata Tertib dan dikuatkan dengan fungsi DPRD Kota Yogyakarta berdasarkan Pasal 4 ayat (1) Nomor 1 Tahun 2018 Tata Tertib DPRD Kota Yogyakarta yaitu DPRD mempunyai fungsi pembentukan Peraturan Daerah, anggaran, dan pengawasan. Ketiga fungsi tersebut dilaksanakan dalam kerangka representasi rakyat di daerah. Selanjutnya, bahwa fungsi pembentukan Peraturan Daerah dapat dilaksanakan yaitu dengan cara:

1. Memberikan usul suatu Rancangan Peraturan Daerah;

2. Membentuk suatu Program Pembentukan Peraturan Daerah bersama dengan kepala daerah; dan

3. Membahas bersama dengan kepala daerah dan tidak menyetujui atau menyetujui Raperda.

Dalam pelaksanaan pembentukan Peraturan Daerah prakarsa DPRD Kota Yogyakarta dapat menggunakan teori negara hukum yang perlu memperhatikan fungsi ketertiban hukum guna dapat dirumuskan dengan baik maka perlu serangkaian langkah terstruktur sesuai dalam Peraturan DPRD Kota Yogyakarta Nomor 1 Tahun 2018 tentang Tatib yang meliputi tahap Perencanaan Penyusunan Raperda, Penyusunan Rancangan Peraturan Daerah, Pembahasan Raperda, Penetapan dan Pengundangan.

\section{Tahap Perencanaan Penyusunan Raperda}

Tahap perencanaan merupakan tahap awal dari perencanaan penyusunan Peraturan Daerah selanjutnya dibahas dalam Program Pembentukan Peraturan Daerah (Propemperda) sebagai upaya untuk penyusunan rencana dan prioritas

${ }^{10}$ Sugiyono, Metode Penelitian Kualitatif Kuantitatif dan R\&D, (Jakarta: Alfabeta, 2003), hlm.11. 
pembentukan Peraturan Daerah dalam kurun waktu 1 tahun anggaran. Prioritas ditentukan berdasarkan aspirasi, kebutuhan daerah, dan perubahan peraturan perundang-undangan yang lebih tinggi.

Rancangan Peraturan Daerah DPRD Kota Yogyakarta dilakukan dengan menyampaikan judul Raperda, materi yang diatur, dan materi yang telah dikaji dituangkan dalam Naskah Akademik. Muatan dari materi Raperda yang telah dikaji pada Naskah Akademik meliputi tujuan penyusunan, latar belakang, dan sasaran yang diwujudkan, termasuk objek, ruang lingkup, pokok pikiran, arah pengaturan maupun jangkauan.

Dewan Perwakilan Rakyat Daerah Kota Yogyakarta setiap tahun melakukan suatu penetapan dan penyusunan Propemperda sebelum penyusunan Rancangan Peraturan Daerah tentang anggaran pengeluaran dan belanja daerah. Anggota DPRD Kota Yogyakarta dan Pemerintah Daerah Kota Yogyakarta melaksanakan penyusunan Propemperda selama 1 tahun sesuai dengan skala prioritas dari pembentukan Raperda.

Mekanisme pembentukan Peraturan Daerah di lingkungan DPRD Kota Yogyakarta yaitu:

1. Penyusunan suatu Propemperda di lingkungan DPRD Kota Yogyakarta dikoordinasikan oleh Badan Pembentukan Peraturan Daerah (Bapemperda);

2. Anggota DPRD Kota Yogyakarta, Gabungan dari Komisi, dan Bapemperda dapat mengusulkan suatu Propemperda;

3. Program Pembentukan Peraturan Daerah disampaikan oleh pemrakarsa kepada Badan Pembentukan Peraturan Daerah disertai dengan Naskah Akademik;

4. Pengkajian program Pembentukan Peraturan Daerah dari pemrakarsa dilakukan oleh Bapemperda bersama Organisasi Perangkat Daerah dan/atau Pemerintah Daerah;

5. Hasil pengkajian Bapemperda terhadap Propemperda pemrakarsa yaitu menerima, menerima dengan bersyarat, atau menolak;

6. Badan Pembentukan Peraturan Daerah menyampaikan suatu rancangan Propemperda kepada Pimpinan Dewan Perwakilan Rakyat Daerah Kota Yogyakarta untuk mendapatkan persetujuan terhadap Propemperda yang diusulan;

7. Rancangan Program Pembentukan Peraturan Daerah ditetapkan menjadi Propemperda Dewan Perwakilan Rakyat Daerah Kota Yogyakarta.

\section{Tahap Penyusunan Rancangan Peraturan Daerah}

Penyusunan Rancangan Peraturan Daerah dilakukan setelah tahap perencanaan selesai. Dalam mengajukan Raperda di lingkungan DPRD Kota Yogyakarta dapat dilaksanakan sesuai dengan Tatib dari DPRD Kota YogyakartaNomor 1 Tahun 2018 yaitu sebagai berikut:

1. Pemrakarsa menyampaikan Raperda kepada Pimpinan DPRD Kota Yogyakarta dalam bentuk tertulis dengan penjelasan atau menyampaikan naskah akademik yang nantinya akan diberi nomor pokok oleh Sekretaris yang bersangkutan;

2. Pimpinan DPRD menyampaikan suatu Rancangan Peraturan Daerah beserta naskah akademik atau penjelasan/keterangan kepada Bapemperda untuk dilakukannya pengharmonisasian, pembulatan, dan pemantapan konsepsi dari Raperda;

3. Hasil Raperda yang telah dilakukan pengkajian dari Bapemperda disampaikan kepada Pimpinan DPRD;

4. Rancangan Perda disampaikan oleh Pimpinan DPRD kepada semua anggota dengan batas waktu 7 hari sebelum rapat paripurna, dengan pembahasan yaitu:

a. Penjelasan dari pemrakarsa;

b. Pandangan dari Anggota DPRD atau Fraksi; dan

c. Pandangan dari Anggota DPRD atau Fraksi dijawab oleh pemrakarsa.

5. Rapat paripurna diakhiri dengan memberikan pendapat berupa persetujuan, penolakan, atau persetujuan dengan perubahan atas usulan Rancangan Perda.

Dari mekanisme penyusunan Rancangan Peraturan Daerah diatas dalam pelaksanaannya di DPRD Kota Yogyakarta pada tahun 2019 dan 2020 hanya mampu mengajukan 4 Rancangan Peraturan Daerah perbandingan yang timpang dengan pihak eksekutif yang dapat mengusulkan 15 rancangan peraturan, yang terjadi dilapangan dikarenakan anggota DPRD Kota Yogyakarta mempunyai kelemahan pada aspek sumber daya manusia yang tidak sesuai dengan dasar keilmuan yang mengakibatkan kurangnya prakarsa Raperda untuk kepentingan masyarakat. Hal tersebut jika dikaitkan dengan konsep demokrasi yang setiap pengambilan kebijakan oleh DPRD merupakan cerminan dari harapan masyarakat dan mengarah pada kepentingan masyarakat maka Anggota DPRD belum maksimal menjadi wadah agresi dari kepentingan rakyat sehingga berdampak pada pembuatan kebijakan yang tidak sesuai harapan masyarakat.

\section{Tahapan Pembahasan Rancangan Peraturan Daerah}

Tahapan pembahasan Rancangan Perda sampai dengan menjadi Perda dilaksanakan melalui 2 tahap pembicaraan berdasarkan Tata Tertib DPRD Kota Yogyakarta Nomor 1 Tahun 2018, Rancangan Peraturan Daerah 
yang telah dipersiapkan oleh DPRD dilakukan pembahasan dengan menyampaikan surat Pimpinan DPRD kepada Kepala Daerah, selanjutnya pembahasan dilakukan dengan pembicaraan tingkat I dan pembicaraan tingkat II.

Pembicaraan tingkat I, dalam hal Rancangan Peraturan Daerah berasal atas prakarsa DPRD maka dilakukan dengan:

1. Rancangan Perda dijelaskan dalam rapat paripurna oleh pimpinan komisi, bapemperda, pimpinan gabungan komisi, atau pimpinan pansus

2. Kepala daerah memberikan suatu pendapat atas Rancangan Perda; dan

3. Fraksi melakukan jawaban atas pendapat dari kepala daerah.

Pembicaraan pada tingkat II, dilakukan dengan:

1. Pengambilan keputusan:

a. Laporan dan hasil pembahasan dari fraksi disampaikan oleh pimpinan komisi, pimpinan pansus, atau pimpinan gabungan pansus;

b. Permintaan persetujuan dalam bentuk lisan dari anggota DPRD diminta oleh pimpinan rapat paripurna.

2. Pendapat akhir kepala daerah.

Bahwa dalam hal Rancangan Peraturan Daerah tidak dapat dilaksanakan secara musyawarah untuk tercapai mufakat maka keputusan akan diambil berdasarkan suara terbanyak. Akan tetapi dalam hal Rancangan Peraturan Daerah tidak mendapatkan persetujuan antara DPRD dan kepala daerah, maka Rancangan Peraturan Daerah tersebut tidak boleh diajukan kembali dalam persidangan DPRD yang masa itu.

\section{Penetapan dan Pengundangan}

Dalam rapat akhir DPRD yang menyatakan Rancangan Perda disetujui, maka Pimpinan DPRD menyampaikan Rancangan Perda untuk kepala daerah melalui sekretariat daerah yaitu biro hukum atau bagian hukum untuk ditetapkan dan diundangkan dalam lembaran daerah. Tahap pengesahan yaitu kepala daerah melakukan tanda tangan dalam rancangan perda dan sekretaris daerah melakukan pengundangan. Sedangkan biro hukum atau bagian hukum bertugas melakukan penomoran Peraturan Daerah, pendistribusian, dan melakukan dokumentasi Peraturan Daerah tersebut.

Berdasarkan pelaksanaan Pembentukan Peraturan Daerah yang sesuai dengan Tata Tertib Peraturan DPRD Kota Yogyakarta Nomor 1 Tahun 2018, maka dapat disimpulkan bahwa DPRD Kota Yogyakarta belum optimal dalam melaksanakan hak anggota dan fungsi legislasinya yang bisa dilihat dari hambatan-hambatan yang terjadi pada pelaksanaan pembentukan Peraturan Daerah Kota Yogyakarta yaitu sebagai berikut:

1. Penyusunan Peraturan Daerah memiliki hambatan seperti perdebatan politik dari pihak DPRD dengan eksekutif yang pembahasannya tidak mengarah kepada kepentingan masyarakat tetapi membahas kepentingan dari lembaganya sehingga mengulur-ulur waktu dalam pembahasan pada pembicaraan tingkat I, seperti pada tahun 2020 ini terdapat 1 Raperda Prakarsa DPRD Kota Yogyakarta yang masih dalam pembicaraan tingkat I karena perbedaan persepsi antara pihak DPRD dan kepala daerah yang mengakibatkan pembahasan sering ditunda.

2. Dalam penyusunan Rancangan Peraturan Daerah sering tidak melibatkan perwakilan dari masyarakat, sehingga pembentukan Peraturan Daerah kurang ide dan tidak inspiratif mengakibatkan produk hukum yang dihasilkan tidak sesuai dengan keadaan hidup masyarakat.

3. Sosialisasi produk hukum yang dilakukan oleh Anggota DPRD Kota Yogyakarta masih kurang, dalam website setwan.jogjakota.go.id informasi yang diberikan belum optimal karena website tersebut tidak menjelaskan sudah sampai mana tahapan Rancangan Perda telah dilaksanakan.

Dalam pembentukan peraturan daerah untuk dinyatakan berhasil maka dapat dilihat pada peran untuk membentuk peraturan daerah yang berasal dari prakarsa DPRD Kota Yogyakarta sampai dengan ditetapkannya peraturan daerah hasil prakarsa, berikut adalah hasil rekapitulasi dari Rancangan Perda atas Prakarsa DPRD Kota Yogyakarta pada Tahun 2019 sampai dengan 2020:11

Tabel 1. Hasil Rekapitulasi Raperda atas Prakarsa DPRD Kota Yogyakarta Tahun 2019-2020

\begin{tabular}{ccccc}
\hline Tahun & Jumlah Raperda & Prakarsa DPRD & Perda yang Sudah Ditetapkan & Perda yang Belum Ditetapkan \\
\hline 2019 & 10 & 3 & 3 & - \\
2020 & 9 & 1 & - & 1 \\
\hline
\end{tabular}

Sumber: Pejabat Sekretariat DPRD Kota Yogyakarta pada 3 September 2020

${ }^{11}$ Hasil wawancara dengan Bapak PA, S.H. selaku Kepala Bagian Perundang-undangan dan Humas Sekretariat DPRD Kota Yogyakarta (wawancara pada 3 September 2020). 
Berdasarkan hasil wawancara dapat diketahui pada tabel diatas memperlihatkan bahwa pada tahun 2019 hingga tahun 2020 jumlah Rancangan Peraturan Daerah yang dibahas bersama sebanyak 19 yang didalamnya terdapat 4 Rancangan Perda hasil prakarsa oleh DPRD Kota Yogyakarta, dari tahun 2019 Raperda prakarsa DPRD Kota Yogyakarta yang sudah ditetapkan berjumlah 3 Peraturan Daerah yaitu Peraturan Daerah Kota Yogyakarta Nomor 1 tahun 2019 tentang Penyelenggaraan Lalu Lintas dan Angkutan Jalan, Peraturan Daerah Kota Yogyakarta Nomor 3 tahun 2019 tentang Penyelenggaraan Bantuan Hukum, dan Peraturan Daerah Kota Yogyakarta Nomor 4 tahun 2019 tentang Pemajuan, Perlindungan, dan Pemenuhan Hak-hak Penyandang Disabilitas. Selanjutnya, pada tahun 2020 terdapat 1 Raperda dari Prakarsa DPRD Kota Yogyakarta yang belum ditetapkan menjadi Peraturan Daerah karena sampai sekarang masih dalam pembicaraan tingkat I yaitu Raperda Pembangunan Ketahanan Keluarga karena ada beberapa Anggota DPRD Kota Yogyakarta terpengaruh untuk tidak melanjutkan pembahasan disebabkan karena perbedaan persepsi antara pihak DPRD Kota Yogyakarta dan pemerintah daerah yang mengakibatkan pembahasan ditunda dan nantinya akan dilakukan penjadwalan ulang untuk dapat menghasilkan kesepakatan bersama.

Tabel diatas menunjukkan bahwa jumlah Raperda pada tahun 2019 hingga tahun 2020 atas prakarsa DPRD Kota Yogyakarta dinilai masih relatif rendah atau sedikit yang hanya mengusulkan 4 Raperda dibandingkan dengan prakarsa eksekutif yang mengusulkan 15 Raperda pada tahun yang sama. Berdasarkan data tersebut, maka Anggota DPRD Kota Yogyakarta perlu bekerja maksimal dalam membangun daerah maupun meningkatkan kesejahteraan untuk masyarakatnya.

Dalam prakteknya Anggota DPRD Kota Yogyakarta kurang optimal dalam menggunakan haknya untuk melaksanakan pembentukan Peraturan Daerah salah satunya disebabkan karena dalam perencanaan anggaran dan waktu yang dialokasikan sangat terbatas sehingga tidak ada cadangan anggaran untuk anggota melakukan prakarsa Raperda dengan demikian anggota DPRD Kota Yogyakarta hanya dapat melaksanakan program prioritas yang telah ditetapkan dalam jangka waktu 1 tahun anggaran. Dalam hal ini perwujudan desentralisasi dibatasi dengan waktu dan anggaran yang dimiliki daerah tersebut sehingga berkurangnya kewenangan mengurus atau mengatur urusan pemerintahan daerahnya.

Dikarenakan minimnya Raperda prakarsa DPRD Kota Yogyakarta di tahun 2019-2020, dapat dianalisis bahwa anggota DPRD Kota Yogyakarta ternyata tidak maksimal dalam melaksanakan haknya untuk mengajukan prakarsa dalam bentuk Raperda sesuai dengan amanat di dalam Pasal 52 huruf a Peraturan Dewan Perwakilan Rakyat Daerah Kota Yogyakarta Nomor 1 Tahun 2018 tentang Tata Tertib. Untuk memperbaiki hal tersebut maka perlu penegasan teori hukum pembangunan dari Mochtar Kusuma-atmadja yaitu hukum sebagai sarana pembangunan dengan memperhatikan peranan atau fungsi hukum dalam masyarakat yang sedang membangun dan di Indonesia dikenali dengan pembangunan nasional atau membangun hukum berdasarkan wawasan nusantara dengan tetap mengutamakan kepastian hukum sehingga mendorong dilakukannya pembentukan peraturan hukum dan melaksanakan teori fungsi legislasi dengan memperhatikan Perwujudan dari fungsi legislasi DPRD salah satunya adalah hak prakarsa dalam mengajukan Rancangan Peraturan Daerah untuk menjadi Peraturan Daerah, keadaan ini memandang patut adanya langkah-langkah yang tepat untuk lebih mengembangkan fungsi legislasi DPRD Kota Yogyakarta dengan menatap organ-organ yang ada dalam DPRD Kota Yogyakarta, meningkatkan kualitas anggota DPRD dengan memperbaiki sistem pemilihan dalam proses rekrutmen untuk menjadi anggota DPRD Kota Yogyakarta, dan memaksimalkan sistem pemerintahan daerah. Dengan demikian harapan-harapan dari dalam diri masyarakat kepada DPRD Kota Yogyakarta sebagai perwakilan rakyat dapat lebih terwujud nyata. Dalam hal ini DPRD Kota Yogyakarta memiliki kesempatan untuk mengembangkan daerahnya lebih baik lagi dengan penerapan teori otonomi daerah melalui desentralisasi yang harapannya menghasilkan sebuah Peraturan Daerah. Dengan demikian untuk mengatasi minimnya prakarsa legislatif maka anggota DPRD Kota Yogyakarta selalu diberikan program pelatihan yang bertujuan memberikan pemahaman terhadap pemerintahan yang baik dan memahami nilai dari otonomi daerah.

Berdasarkan penelitian di atas, maka pelaksanaan pembentukan Peraturan Daerah prakarsa DPRD Kota Yogyakarta pada tahun 2019 hingga tahun 2020 dinilai belum optimal dalam kinerjanya mengusulkan Raperda dibandingkan dengan prakarsa dari pihak eksekutif yang lebih banyak, maka DPRD Kota Yogyakarta dengan melihat kinerjanya sendiri pada tahun 2019 hingga tahun 2020 dapat mengevalusi kekurangan dan memaksimalkan 3 tahun sisa kinerja di tahun 2021 sampai dengan tahun 2024 untuk meningkatkan kuantitas dan kualitas pembentukan Peraturan Daerah prakarsa DPRD menjadi lebih maksimal dan baik.

\section{Faktor-faktor Yang Mempengaruhi Kinerja Anggota DPRD Kota Yogyakarta Dalam Melaksanakan Fungsi Pembentukan Peraturan Daerah}

Anggota DPRD Kota Yogyakarta dinilai masih kurang dalam melaksanakan kinerjanya untuk mengusulkan Rancangan Peraturan Daerah sehingga dari segi kuantitas Peraturan Daerah yang disahkan pada tahun 2019 hingga 2020 masih minim. Berdasarkan hasil wawancara dapat diketahui bahwa dalam pembentukan Peraturan Daerah atas prakarsa DPRD Kota Yogyakarta yang mengakibatkan belum optimal dipengaruhi beberapa faktor yaitu kurangnya 
pengalaman berorganisasi anggota DPRD Kota Yogyakarta, latar belakang pendidikan yang berbeda dan masih terbatas, masyarakat kurang antusias berpartisipasi dalam pembentukan Peraturan Daerah dengan penjelasan sebagai berikut: ${ }^{12}$

\section{Pengalaman Berorganisasi Anggota DPRD Kota Yogyakarta}

Dalam rangka mengoptimalkan pelaksanaan fungsi legislasi maka anggota DPRD dituntut untuk memiliki kualitas sumber daya manusia yang handal dan memiliki pengalaman pada bidang legislasi, kerena dua hal tersebut dapat mendukung pengoptimalisasian fungsi legislasi dari anggota DPRD sehingga dapat maksimal dalam menghasilkan Peraturan Daerah. ${ }^{13}$ Dalam kelancaran melaksanakan fungsi pembentukan Peraturan Daerah maka Anggota DPRD Kota Yogyakarta sangat penting untuk memiliki pengalaman berorganisasi seperti memiliki riwayat jabatan atau pengalaman dalam berbagai organisasi. Pengalaman yang berpengaruh dalam pembentukan Peraturan Daerah adalah anggota DPRD yang pernah menjabat sebagai dewan pada periode sebelumnya sehingga kekurangan yang ada pada periode sebelumnya dapat diperbaiki pada periode selanjutnya dengan langkah yang lebih tepat. Tabel dibawah ini memperlihatkan jumlah anggota DPRD Kota Yogyakarta periode sebelumnya menjabat lagi pada periode 2019-2024, jelasnya dapat dilihat pada Tabel:

Tabel 2. Pengalaman Menjadi Anggota DPRD Kota Yogyakarta Periode 2019-2024

\begin{tabular}{cll}
\hline No. & Pengalaman & Jumlah Orang \\
\hline 1 & Pertama Kali & 20 \\
2 & Dua Kali & 20 \\
& & 40
\end{tabular}

Sumber: Anggota DPRD Kota Yogyakarta.

DPRD Kota Yogyakarta periode 2019-2024 memiliki 40 anggota yang 50 persennya merupakan anggota baru. Komposisi Anggota DPRD Kota Yogyakarta yang pertama kali duduk sebagai wakil rakyat sebanyak 20 orang, sedangkan 20 orang lainnya merupakan anggota dewan periode lama. Karena mereka yang sudah berpengalaman akan ditempatkan pada jabatan-jabatan yang penting di DPRD Kota Yogyakarta, seperti pimpinan komisi, sekretaris komisi, ketua fraksi, dan sekretaris fraksi. Dalam menjalankan tugas sebagai wakil rakyat pengalaman organisasi tidak selalu pernah menjabat anggota legislatif periode sebelumnya, bisa juga yang berasal dari Pegawai Negeri Sipil atau birokrat yang berpengalaman dan memahami dalam hal membahas anggaran, mengajukan anggaran belanja, dan memimpin rapat/sidang dan mengevalusi rapat.

Dapat disimpulkan bahwa pengalaman merupakan salah satu faktor penting dalam melaksanakan pembentukan Peraturan Daerah, kurangnya pengalaman berpengaruh pada kemampuan dalam prakarsa DPRD Kota Yogyakarta yang masih minim dibandingkan pihak eksekutif yang memiliki SDM yang berbeda dengan pihak legislatif dari segi jenjang pendidikan dan rekrutmen pihak eksekutif lebih baik sehingga hanya SDM tertentu yang dapat menduduki jabatan sebagai pengambil kebijakan, berbeda dengan DPRD Kota Yogyakarta dari segi disiplin ilmu dan pengalaman yang dimiliki tidak sesuai dengan tugas yang dilaksanakan. Maka pengaruh penting pengalaman yang dimiliki oleh anggota DPRD dapat memberikan hasil untuk melakukan pengambilan kebijakan yang tepat dengan cara menggali informasi yang semestinya. Untuk mengatasi keterbatasan pengalaman yang dimiliki anggota DPRD Kota Yogyakarta maka dibutuhkannya tenaga ahli yang sesuai dalam bidangnya sehingga perlu kerjasama dengan Perguruan Tinggi di Yogyakarta sebagai tenaga ahli.

\section{Latar Belakang Pendidikan Anggota DPRD Kota Yogyakarta}

Persyaratan menjadi Anggota DPRD setidaknya berpendidikan paling rendah yaitu tamat sekolah menengah atas atau sederajat, seperti pada Anggota DPRD Kota Yogyakarta yang berasal dari latar belakang pendidikan yang berbeda, sehingga mengakibatkan kemampuan dalam pembuatan Rancangan Peraturan Daerah menjadi minim dikarenakan kurang memahami proses prakarsa dan pembentukan Raperda. Maka dari itu perlunya peningkatan kapasitas atau pengetahuan bagi seluruh Anggota DPRD Kota Yogyakarta, peningkatan kapasitas dapat dilaksanakan dalam bentuk Bimbingan Teknis pembentukan Peraturan Daerah. Dalam proses belajar membuat Raperda membutuhkan waktu yang tidak sebentar, maka partai politik harus mempersiapkan kadernya sehingga sudah paham dan dapat terjun di kelembagaan DPRD.

${ }^{12}$ Hasil wawancara dengan Bapak PA, S.H. selaku Kepala Bagian Perundang-undangan dan Humas Sekretariat DPRD Kota Yogyakarta (wawancara pada 3 September 2020).

${ }^{13}$ Fahmi Afrizal Kaisupy. Wahab Tuanaya, Marno Wance. "Peran Anggota Legislatif Dalam Pembuatan Peraturan Daerah Kabupaten Seram Bagian Barat", Jurnal Moderat, Vol. 6 No. 2, (Mei 2020) : 413. 
Upaya dari pihak DPRD Kota Yogyakarta untuk meningkatkan kemampuan pembentukkan Peraturan Daerah sesuai keterangan yang didapat dari narasumber bahwa Anggota DPRD Kota Yogyakarta telah melaksanakan peningkatan kapasitas melalui bimbingan teknis pembentukan Peraturan Daerah, namun kenyataannya bimtek yang sudah dilaksanakan terlupakan bahkan dalam penerapannya anggota DPRD Kota Yogyakarta masih terkendala dalam pemahamannya untuk penyusunan naskah akademik dan Rancangan Peraturan Daerah yang sering disalahkan oleh biro hukum karena melakukan copy paste dengan peraturan perundang-undangan yang sudah ada. Untuk mengatasi hal tersebut maka pihak DPRD Kota Yogyakarta harus secara rutin melaksanakan bimbingan teknis untuk meningkatkan profesinya yang berisikan materi pelaksanaan pembentukan Rancangan Peraturan Daerah, pemahaman tentang tata cara atau aturan terkait dengan fungsi dan tugas sebagai anggota DPRD bisa dilaksanakan dengan mendatangkan narasumber dari akademisi ataupun praktisi hukum sebagai pembelajaran pengalaman terutama untuk anggota baru yang bukan merupakan dari latar pendidikan sarjana hukum sehingga anggota DPRD Kota Yogyakarta dalam melaksanakan pekerjaannya akan mendapatkan hasil kinerja yang tinggi.

\section{Masyarakat Kurang Antusias Berpartisipasi Dalam Pembentukan Peraturan Daerah}

Partisipasi masyarakat dalam penyusunan Raperda akan menghasilkan legistimasi produk hukum DPRD, partisipasi dalam konteks ini dapat dikatakan legitimasi penyelenggaraan negara tidak hanya pada pemilihan umum saja, akan tetapi berdampak pada pentingnya demokrasi partisipatif, sehingga partisipasi dalam pembentukan Perda dengan mengikutsertakan pihak diluar DPRD Kota Yogyakarta menjadi sangat penting, karena dapat menjaring pengalaman atau keahlian masyarakat sehingga Perda yang dihasilkan sesuai dengan harapan masyarakat dan tidak bertentangan dengan hierarki peraturan perundang-undangan.

Anggota DPRD Kota Yogyakarta telah melakukan penjaringan aspirasi masyarakat untuk melaksanakan penyusunan Raperda dan selama ini masyarakat dinilai tidak antusias dan tidak kooperatif karena sepanjang tidak menyinggung keberlangsungan hidupnya masyarakat tidak perduli terhadap pembentukan Peraturan Daerah di DPRD Kota Yogyakarta, sehingga yang dilakukan oleh DPRD Kota Yogyakarta selama ini telah melakukan kerjasama dengan tokoh masyarakat atau perguruan tinggi untuk memfasilitasi rapat untuk memberikan aspirasinya kepada anggota dewan, akan tetapi hal tersebut dinilai tidak maksimal karena terdapat indikasi bahwa aspirasi yang disampaikan memuat kepentingan tertentu maupun golongan. Upaya untuk menghindari adanya aspirasi kepentingan tertentu maka selalu dibutuhkan pengawalan dalam setiap proses seperti dibentuknya pansus atau fraksi yang harus mengawal proses Rancangan Peraturan Daerah tersebut. Anggota DPRD Kota Yogyakarta harus aktif dalam menjaring informasi ataupun aspirasi dari masyarakat sehingga lebih inspiratif dan kaya ide dalam pembentukan Peraturan Daerah sesuai kebutuhan masyarakat.

\section{SIMPULAN}

Berdasarkan hasil dan pembahasan, maka dengan ini kesimpulan yang dapat ditarik yaitu:

1. Pelaksanaan fungsi legislasi DPRD Kota Yogyakarta dalam prakarsa pembentukan Peraturan Daerah berdasarkan Peraturan Dewan Perwakilan Rakyat Daerah Kota Yogyakarta Momor 1 Tahun 2018 tentang Tata Tertib dalam mekanisme penyusunan Peraturan Daerah mulai dari tahap Perencanaan sampai dengan tahap Penetapan dan Pengundangan Peraturan Daerah belum berjalan dengan maksimal sehingga dengan melihat kinerjanya sendiri pada tahun 2019 hingga 2020 maka anggota DPRD Kota Yogyakarta dapat mengevaluasi kekurangan dan memaksimalkan 3 tahun sisa kinerjanya ditahun 2021 sampai dengan 2024 untuk meningkatkan kuantitas dan kualitas dalam pembentukan Peraturan Daerah atas prakarsa DPRD Kota Yogyakarta.

2. Faktor-faktor yang mempengaruhi kinerja anggota DPRD Kota Yogyakarta dalam melaksanakan fungsi pembentukan Peraturan Daerah yang mengakibatkan belum optimal yaitu kurangnya pengalaman berorganisasi anggota DPRD Kota Yogyakarta, latar belakang pendidikan anggota DPRD Kota Yogyakarta yang mempunyai tingkat pendidikan yang berbeda, dan masyarakat kurang antusias berpartisipasi dalam pembentukan Peraturan Daerah.

\section{DAFTAR PUSTAKA}

\section{Buku}

Asmorojati, Anom Wahyu, Hukum Pemerintahan Daerah \& Daerah Istimewa Yogyakarta Dalam Bingkai NKRI. Yogyakarta: UAD Press, 2020.

Sirajuddin, Hukum Administrasi Pemerintah Daerah. Malang: Setara Press, 2016.

Huda, Ni'Matul, Otonomi Daerah, Filosofi, Sejarah Perkembangan dan Problematika, Yogyakarta: Pustaka Belajar, 2013.

Gaffar, Janedjri M, Demokrasi dan pemilu di Indonesia, Jakarta: Konstitusi Press, 2013.

Ngani, Nico, Metodologi Penelitian dan Penulisan Hukum, Yogyakarta: Pustaka Yustisia, 2012. 
Sugiyono, Metode Penelitian Kualitatif Kuantitatif dan R\&D, Jakarta: Alfabeta, 2003.

\section{Jurnal}

Fahmi Afrizal Kaisupy. Wahab Tuanaya, Marno Wance. "Peran Anggota Legislatif Dalam Pembuatan Peraturan Daerah Kabupaten Seram Bagian Barat", Jurnal Moderat, Vol. 6 No. 2, (Mei 2020): 413.

Rosiani Pratiwi. "Pelaksanaan Fungsi Legislasi Dewan Perwakilan Rakyat Daerah Kabupaten Sanggau Dalam Pembuatan Peraturan Daerah Tahun 2017", Jurnal fisipuntan, Vol. 7 No. 2, (Juni 2019): 7.

Fioren Maria Lasut. "Analisis Fungsi Legislasi Dewan Perwakilan Rakyat Daerah (DPRD) Kota Manado Dalam Pembentukan Peraturan Daerah", Jurnal Lex Administratum, Vol. 6 No. 4, (September 2018): 124.

Moh Rusli Syuaib. "Fungsi Dewan Perwakilan Rakyat Daerah (DPRD) Dalam Pelaksanaan Otonomi Daerah di Kabupaten Poso". Jurnal Ilmiah Administratie, Vol. 2 No. 2, (2014): 30.

Dayanto. "Pendayagunaan Hak Inisiatif Anggota DPRD Dalam Pembentukan Peraturan Daerah (Studi Yuridis Sosiologis Di DPRD Sulawesi Selatan)", Jurnal Hukum dan Syariah: Tahkim, Vol. 10 No. 2, (Desember 2014): 147.

\section{Peraturan Perundang-undangan}

Undang-Undang Dasar Negara Republik Indonesia Tahun 1945.

Undang-Undang Nomor 15 Tahun 2019 tentang Perubahan Atas Undang-Undang Nomor 12 Tahun 2011 tentang Pembentukan Peraturan Perundang-Undangan.

Undang-Undang Republik Indonesia Nomor 42 Tahun 2014 tentang Perubahan Atas Undang-Undang Nomor 17 Tahun 2014 tentang Majelis Permusyawaratan Rakyat, Dewan Perwakilan Rakyat, Dewan Perwakilan Daerah, dan Dewan Perwakilan Rakyat Daerah.

Undang-Undang Republik Indonesia Nomor 9 Tahun 2015 tentang Perubahan Kedua Atas Undang-Undang Nomor 23 Tahun 2014 tentang Pemerintahan Daerah.

Peraturan Dewan Perwakilan Rakyat Daerah Kota Yogyakarta Nomor 1 Tahun 2018 tentang Tata Tertib. 